\title{
Relationships among postharvest ripening attributes and storage disorders in 'Honeycrisp' apple
}

Behrouz EhSANI-Moghaddam, Jennifer R. DeELL *

Ontario Ministry of Agriculture, Food, and Rural Affairs, P.O. Box 587, Simcoe, ON, Canada N3Y 4N5, jennifer.DeEII@ontario.ca
* Correspondence and reprints

Received 19 June 2012 Accepted 16 August 2012

Fruits, 2013, vol. 68, p. 323-332 (C) 2013 Cirad/EDP Sciences All rights reserved DOI: $10.1051 /$ fruits/2013078 www.fruits-journal.org

RESUMEN ESPAÑOL, p. 332
Relationships among postharvest ripening attributes and storage disorders in 'Honeycrisp' apple.

Abstract - Introduction. The objective of this study was to examine the relationships among the ripening attributes of 'Honeycrisp' apples at harvest and after storage, and the direct and indirect contributions of these attributes to peel greasiness and the incidence of soft scald and soggy breakdown during storage using correlation and path-coefficient analyses. Materials and methods. Fruit were harvested from a commercial orchard at least five times throughout the commercial harvest period during four subsequent years (2008 to 2011). In two of the years, fruit were stored in air for 3 months at $3{ }^{\circ} \mathrm{C}$ and/or in a controlled atmosphere $(1-2 \mathrm{kPa}$ $\mathrm{O}_{2}+1-2 \mathrm{kPa} \mathrm{CO}_{2}$ ) for 6 months at $3{ }^{\circ} \mathrm{C}$. Fruit were analyzed at harvest and after storage. Results and discussion. Negative correlations were detected between internal ethylene concentration (IEC) and soluble solids concentration (SSC) or titratable acidity (TA) (the higher the IEC, the lower the SSC and TA) and a positive correlation between firmness and TA (the higher the firmness, the higher the TA). More peel greasiness and higher incidence of soggy breakdown during storage were associated with lower firmness, SSC and TA. Negative correlations were also detected between the incidence of soft scald and IEC or peel greasiness. The results of the path-coefficient analyses suggest that, in 'Honeycrisp', interrelationships among postharvest ripening indices and each individual disorder differ. Three possible path models for the interrelationships among ripening attributes (independent variables) and the incidence of peel greasiness, soft scald and soggy breakdown (dependent variables) are presented.

Canada / Malus / apples / postharvest ripening / postharvest decay / quality

Relations entre les caractéristiques de maturation après récolte et les anomalies de conservation chez la pomme 'Honeycrisp'.

Résumé - Introduction. L'objectif de notre étude a été d'étudier les relations entre certaines caractéristiques de maturation des pommes 'Honeycrisp' à la récolte et après stockage et les contributions directes et indirectes de ces caractéristiques sur l'aspect graisseux de la peau, l'échaudure molle et la vitrescence des fruits pendant leur conservation ; des analyses de corrélation et de coefficient des chemins ont été utilisées. Matériel et méthodes. Les fruits ont été récoltés dans un verger commercial au moins cinq fois au cours de la période de récolte commerciale lors des quatre années 2008 à 2011. Durant deux de ces années, les fruits ont été stockés à l'air pendant 3 mois à $3{ }^{\circ} \mathrm{C}$ et/ou en atmosphère contrôlée $\left(1-2 \mathrm{kPa} \mathrm{O}_{2}+1-2 \mathrm{kPa} \mathrm{CO} 2\right)$ pendant 6 mois à $3{ }^{\circ} \mathrm{C}$. Les fruits ont été analysés à la récolte et après stockage. Résultats et discussion. Des corrélations négatives ont été détectées entre la concentration interne d'éthylène (CIT) et la concentration en solides solubles (CSS) ou l'acidité titrable (AT) (plus la CIT a été élevée, plus la CSS et l'AT ont été faibles) et des corrélations positives sont apparues entre la fermeté et l'AT (plus la fermeté a été élevée, plus l'AT a été importante). Pendant le stockage des pommes, davantage de graisse sur la peau et de vitrescence ont été associées à une moindre fermeté, et à de faibles valeurs de CSS et d'AT. Des corrélations négatives ont également été détectées entre l'incidence de l'échaudure molle et la CIT ou la peau grasse. Les résultats des analyses de coefficient des chemins suggèrent que, pour la pomme 'Honeycrisp', les interrelations entre les caractéristiques de maturation après récolte et chacune des anomalies de stockage considérées individuellement sont différentes. Trois modèles de chemins possibles montrant l'interrelation entre les caractéristiques de maturation (variables indépendantes) et l'aspect graisseux de la peau, l'échaudure molle et la vitrescence (variables dépendantes) ont été présentés.

Canada / Malus / pomme / maturation après récolte / maladie postrécolte / qualité 


\section{Introduction}

'Honeycrisp' is a popular apple cultivar with exceptional flavour, as it remains crisp and juicy for several months in storage. However, 'Honeycrisp' apples are chilling-sensitive and, therefore, susceptible to soft scald and soggy breakdown, which limit commercial storage duration [1, 2]. Soft scald (syn deep scald, ribbon scald) is characterized by sharply defined, irregularly shaped brown lesions on the apple skin, which can extend beneath the skin into the flesh [3, 4]. Soggy breakdown is an internal disorder, which in severe cases can cause complete browning of the flesh, with soft and spongy tissue.

The role of ethylene in the development of physiological disorders, including chilling-related injuries, has been investigated in various apple cultivars [5-7]. Inhibition of ethylene production, either due to storage at $0.5^{\circ} \mathrm{C}$ or postharvest treatment with 1 methylcyclopropene (1-MCP), can cause stress and damage to cells and result in higher polyphenol oxidase activity that leads to progressive flesh browning development in 'Empire' apples during storage [8]. Preharvest inhibition of ethylene by 1-MCP application in the orchard has been shown to reduce soft scald development in 'Honeycrisp', whereas postharvest treatment with 1-MCP has little effect [4].

'Honeycrisp' has unique quality characteristics and generally does not mature or senesce in the same manner as other apple cultivars. It remains crisp during ripening, which can be attributed to the maintenance of high turgor potential and cell wall integrity, instead of softening and becoming mealy like other apple cultivars [9]. Standard maturity indices, such as internal ethylene concentration (IEC), fruit firmness, soluble solids concentration (SSC) and starch content, do not show consistent patterns of change over time [10]. Ethylene inhibition by postharvest treatment with 1-MCP results in higher SSC in 'Honeycrisp' after storage [11], whereas typically there is no consistent effect of 1-MCP on SSC [7, 12]. To reduce soft scald and soggy breakdown development, 'Honeycrisp' apples are generally preconditioned at warmer temperatures $\left(10^{\circ} \mathrm{C}\right.$ or $20^{\circ} \mathrm{C}$ ) for 1 week prior to storage at $3{ }^{\circ} \mathrm{C}$ [2].
However, such preconditioning can reduce titratable acidity (TA) in 'Honeycrisp' apples [13].

Using the statistical techniques of correlation and path-coefficient analyses, relationships among quality indices after storage and their association with physiological disorders have been reported for 'Empire' and 'Ambrosia' apples [14]. The objective of this study was to examine the nature of the relationships among IEC and other maturity indices during the harvest period and after storage, as well as their influence on soft scald, soggy breakdown and peel greasiness in the unique 'Honeycrisp' apple.

\section{Materials and methods}

\subsection{Plant material and treatments}

'Honeycrisp' apples (Malus $\times$ domestica Borkh.) were obtained from a commercial orchard in Norfolk County, Ontario (Canada) a minimum of five times throughout the commercial harvest period during four subsequent years (from 2008 to 2011). In two of these years (2009 and 2010), fruit were stored in air for 3 months at $3{ }^{\circ} \mathrm{C}$ or in a controlled atmosphere (CA) (1-2 $\left.\mathrm{kPa} \mathrm{O}_{2}+1-2 \mathrm{kPaCO}_{2}\right)$ for 6 months at $3{ }^{\circ} \mathrm{C}$. Data obtained from fruit maturity evaluations at harvest and fruit assessments after storage were used for the various statistical analyses. The use of storage regimes was simply to obtain apples with a wide range of ripening attributes.

\subsection{Fruit quality evaluations}

Fruit maturity evaluations during the harvest period included assessments of the internal ethylene concentration (IEC), firmness, soluble solids concentration (SSC), titratable acidity (TA), size (apple diameter), blush (percentage) and starch index. Quality evaluations after storage included IEC, firmness, SSC and TA, as well as peel greasiness and incidence of soft scald and soggy breakdown. All attributes were measured using at least three 10-apple samples at each time 
point. Post-storage evaluations were made after 1 and 7 days at $\sim 21{ }^{\circ} \mathrm{C}$.

Internal ethylene concentration was determined by withdrawing a 3-mL gas sample from the core of each fruit using a syringe and injecting the sample into a Varian CP3800 gas chromatograph (Varian Canada Inc., Mississauga, ON) equipped with a 0.5-mL sample loop, flame ionization detector (FID), and $15 \mathrm{~m} \times 0.32 \mathrm{~mm}$ Restek RtSPLOT $^{\mathrm{TM}}$ capillary column (Chromatographic Specialties Inc., Brockville, ON, Canada). The injector, column and detector temperatures were $(120,35 \text { and } 225)^{\circ} \mathrm{C}$, respectively. High-grade helium was used as the carrier gas at a flow rate of $0.37 \mathrm{~mL} \cdot \mathrm{s}^{-1}$ with a typical run time of $2 \mathrm{~min}$.

Fruit firmness was measured at two opposite sides on the equator of each fruit after peel removal, using a Fruit Texture Analyzer (FTA) machine fitted with an 11-mm tip (GÜSS, South Africa). Freshly prepared blended juice collected from 10 apples using one slice per sample was used for SSC and TA measurements. The soluble solids concentration was determined using a digital refractometer (PR-32, Atago Co., Ltd., Japan) and TA (expressed as mg Eq malic acid $100 \mathrm{~mL}$ juice) was measured by titrating a 2-mL juice sample with $0.1 \mathrm{~N} \mathrm{NaOH}$ to an end point of $\mathrm{pH} 8.1$ (as indicated by phenolphthalein). Starch content was estimated using the Cornell Generic Starch Chart [15] Apples were cut in half at the equator and rated on a scale of 1 to 8 , where $1=100 \%$ starch staining and $8=0 \%$ staining.

The epidermal greasiness of the fruit was measured subjectively by the feel of the skin by the same examiner and scored as follows: 1 = none to slight greasiness; 2 = moderate greasiness; 3 = severe greasiness (slippery to touch). Incidence of soft scald and soggy breakdown were calculated as a percentage, regardless of the severity of the disorder.

\subsection{Statistical analysis}

Data obtained from IEC, firmness, SSC, TA, apple size, blush $\%$ and starch at harvest, and IEC, firmness, SSC and TA after storage were used for Pearson correlation (simple correlation) analyses. The four ripening indices after storage along with the incidence of storage disorders (soft scald, soggy breakdown and peel greasiness) were used for path-coefficient analyses.

The Pearson correlation coefficient $(r)$ was calculated between the ripening indices and the storage disorders as well as among themselves, to indicate the relationship between the two values in terms of direct or cause-effect [16]. The following assumptions were considered before analysis: 1) relationships among variables are linear and there is no interaction effect among them, 2) residual variables are uncorrelated with any of the variables other than the one they cause, or any endogenous variable, and 3) for any endogenous variable, there is one-way causal flow.

After correlation analyses, the following relationships were noted: 1) a positive correlation between two ripening values (the higher one ripening value, the higher another value), 2) a negative correlation between two ripening indices (the higher one ripening value, the lower another value), and 3) no correlation between the two ripening variables.

The Proc corr and Proc IML procedures of the SAS system (version 9.2, SAS Inst.) were used for the Pearson's correlation and path-coefficient analyses, respectively. The following equation was also used for pathcoefficient analyses: $\left[\mathrm{r}_{\mathrm{ij}}\right] \times\left[\mathrm{P}_{\mathrm{i}-\mathrm{Y}}\right]=\left[\mathrm{r}_{\mathrm{i}-\mathrm{Y}}\right]$, where $\left[r_{i j}\right]$ was the matrix of simple correlations among the values of ripening indices, $\left[\mathrm{P}_{\mathrm{i}-\mathrm{Y}}\right]$ was the matrix of path coefficients, and $\left[\mathrm{r}_{\mathrm{i}-\mathrm{Y}}\right]$ was the matrix of simple correlations between the values of ripening indices and the response variable.

Internal ethylene concentration was considered the independent variable, while the other ripening attributes and physiological disorders were considered the dependent variables. Moreover, if $|p| \leq 0.05$ then the path was ignored for further analyses.

\section{Results and discussion}

The range of fruit maturity throughout the harvest period was recorded (table I). 
Table I.

Mean, standard deviation, and minimum and maximum maturity indices of 'Honeycrisp' apples at harvest time over 4 years.

\begin{tabular}{|c|c|c|c|c|c|c|c|}
\hline Parameters & $\begin{array}{c}\text { IEC } \\
\left(\mu \mathrm{L} \cdot \mathrm{L}^{-1}\right)\end{array}$ & $\begin{array}{l}\text { Firmness } \\
(\mathrm{N})\end{array}$ & $\begin{array}{c}\mathrm{SSC}^{\mathrm{b}} \\
(\%)\end{array}$ & $\begin{array}{c}\text { Malic acid } \\
\text { (mg.100 mL juice) }\end{array}$ & $\begin{array}{l}\text { Diameter } \\
\text { (cm) }\end{array}$ & $\begin{array}{c}\text { Blush } \\
(\%)\end{array}$ & $\begin{array}{l}\text { Starch }^{\mathrm{C}} \\
(1-8)\end{array}$ \\
\hline Mean & 14.6 & 65.4 & 13.5 & 609 & 8.1 & 75 & 6.8 \\
\hline Standard deviation & 25.7 & 1.7 & 1.3 & 106 & 0.9 & 16 & 1.3 \\
\hline Minimum & 0 & 43.6 & 10.9 & 369 & 6.0 & 20 & 1.0 \\
\hline Maximum & 161.6 & 94.3 & 16.9 & 838 & 10.0 & 100 & 8.0 \\
\hline
\end{tabular}

Table II.

Mean, standard deviation, minimum and maximum internal ethylene concentration (IEC), firmness, soluble solids concentration (SSC), malic acid and storage disorders in 'Honeycrisp' apples stored for 3 months in air or 6 months in $\mathrm{CA}\left(1-2 \mathrm{kPa} \mathrm{O}_{2}+1-2 \mathrm{kPa} \mathrm{CO}\right)$ at $3{ }^{\circ} \mathrm{C}$, plus $1 \mathrm{~d}$ or $7 \mathrm{~d}$ at $21^{\circ} \mathrm{C}$ over 2 years.

$\begin{array}{lccccccc}\text { Parameters } & \begin{array}{c}\text { IEC } \\ \left(\mu \mathrm{L} \cdot \mathrm{L}^{-1}\right)\end{array} & \begin{array}{c}\text { Firmness } \\ (\mathrm{N})\end{array} & \begin{array}{c}\text { SSC } \\ (\%)\end{array} & \begin{array}{c}\text { Malic acid } \\ (\mathrm{mg} \cdot 100 \mathrm{~mL} \text { juice })\end{array} & \begin{array}{c}\text { Greasiness } \\ (1-3)\end{array} & \begin{array}{c}\text { Soft scald } \\ (\%)\end{array} & \begin{array}{c}\text { Soggy breakdown } \\ (\%)\end{array} \\ \text { Mean } & 58.7 & 65.4 & 12.7 & 481 & 2.0 & 23.4 & 12.0 \\ \text { Standard deviation } & 48.8 & 1.6 & 0.9 & 97 & 1.1 & 26.9 & 18.4 \\ \text { Minimum } & 0.4 & 40.9 & 10.0 & 268 & 0 & 0 & 0 \\ \text { Maximum } & 187.0 & 74.3 & 14.3 & 704 & 3.0 & 100 & 74.4\end{array}$

a Epidermal greasiness: 1 = none to slight greasiness (slightly noticeable by feel); 2 = moderate greasiness; $3=$ severe greasiness (slippery to touch).

Simple statistics for the ripening attributes after storage, as well as peel greasiness and the incidence of soft scald and soggy breakdown, showed that peel greasiness ranged from 0 to 3, while soft scald was $0 \%$ to $100 \%$, and soggy breakdown $0 \%$ to $74 \%$ incidence (table II).

The various storage treatments caused enough variation in the ripening attributes to allow for comprehensive statistical analyses. The effects of specific storage regimes will not be discussed, since the objective of this study was to investigate relationships among ripening attributes and postharvest disorders.

Maturity at harvest is the most decisive factor for storage life and final fruit quality. Ethylene production has a major role in apple fruit ripening and determining potential storability [17]. Internal ethylene concentration was consistently correlated negatively with SSC and TA during the harvest period $(r=-0.24$ and $r=-0.54$, respectively, table III) and after storage $(r=-0.49$ and $r=$ -0.52 , respectively, table IV). This indicates that the higher the IEC, the lower the SSC and TA. Such associations are typical in apple ripening after storage and similar relationships have been found in 'Empire' apples [14]. Internal ethylene concentration was also correlated positively with the starch index in 'Honeycrisp' during the harvest period ( $r=0.31)$ (table III). Therefore, starch degradation advanced as IEC increased in the fruit.

There was a positive association between firmness and TA at harvest $(r=0.39$, table III) and after storage $(r=0.68$, table $I V)$. Firmness was correlated negatively with fruit size $(r=-0.32)$ and the starch index $(r=-0.46)$ at harvest, while size and starch were correlated positively $(r=0.34)$ (table III). 
Table III.

Pearson correlation coefficients (r) among ripening indices in 'Honeycrisp' apples at harvest, over 4 years.

\begin{tabular}{|c|c|c|c|c|c|c|c|}
\hline Variable & $\mathrm{IEC}^{\mathrm{a}}$ & Firmness & $\mathrm{SSC}^{\mathrm{b}}$ & $\mathrm{TA}^{\mathrm{C}}$ & Size & Blush & Starch \\
\hline $\mathrm{IEC}^{\mathrm{a}}$ & 1 & -0.12 & $-0.24^{*}$ & $-0.54^{\star \star \star \star \star}$ & 0.03 & -0.02 & $0.31^{\star \star \star \star \star}$ \\
\hline Firmness & - & 1 & 0.04 & $0.39^{\star \star \star \star}$ & $-0.32^{* \star \star *}$ & -0.03 & $-0.46^{\star \star \star \star}$ \\
\hline $\mathrm{SSC}^{\mathrm{b}}$ & - & - & 1 & $0.25^{* *}$ & 0.30 ** & $0.32^{\star \star \star}$ & 0.14 \\
\hline $\mathrm{TA}^{\mathrm{C}}$ & - & - & - & 1 & 0.08 & 0.17 & $-0.33^{\star \star *}$ \\
\hline Size & - & - & - & - & 1 & $0.28^{\star \star \star}$ & $0.34^{\star \star \star \star}$ \\
\hline Blush & - & - & - & - & - & 1 & 0.22 *** \\
\hline Starch & - & - & - & - & - & - & 1 \\
\hline
\end{tabular}

Table IV.

Pearson correlation coefficients $(r)$ among ripening indices and physiological disorders in 'Honeycrisp' apples stored for up to 6 months, then held for $1 \mathrm{~d}$ and $7 \mathrm{~d}$ at $21^{\circ} \mathrm{C}$ over 2 years.

\begin{tabular}{|c|c|c|c|c|c|c|c|}
\hline Variable & $\mathrm{IEC}^{\mathrm{a}}$ & Firmness & $\mathrm{SSC}^{\mathrm{b}}$ & $\mathrm{TA}^{\mathrm{C}}$ & Peel greasiness & Soft scald & Soggy breakdown \\
\hline $\mathrm{IEC}^{\mathrm{a}}$ & 1 & 0.05 & $-0.49^{\star * \star}$ & $-0.52^{* \star \star \star}$ & $0.49^{\star \star \star}$ & $-0.35^{*}$ & 0.21 \\
\hline Firmness & - & 1 & 0 & $0.68^{* * \star *}$ & -0.28 * & 0.06 & $-0.71^{\star \star \star \star}$ \\
\hline $\mathrm{SSC}^{\mathrm{b}}$ & - & - & 1 & 0.19 & $-0.50^{\star \star \star \star}$ & $0.30^{*}$ & -0.32 ** \\
\hline $\mathrm{TA}^{\mathrm{C}}$ & - & - & - & 1 & $-0.50^{\star \star \star \star}$ & 0.07 & $-0.59^{\star \star \star \star}$ \\
\hline Peel greasiness & - & - & - & - & 1 & $-0.66^{\star \star \star \star}$ & $0.33^{* *}$ \\
\hline Soft scald & - & - & - & - & - & 1 & -0.20 \\
\hline Soggy breakdown & - & - & - & - & - & - & 1 \\
\hline
\end{tabular}

This indicates that larger fruit were softer and had less starch than smaller fruit. Fruit size has long been known as a factor affecting firmness [18, 19], but size alone is oversimplification since it relates to both cell number and cell size [20]. In a recent study investigating cropping effects on 'Royal Gala' apple, fruit dry matter concentration was found to have a greater effect on firmness than actual fruit size [21].

Fruit size was also correlated positively with SSC $(r=0.30)$ and the percentage of red blush $(r=0.28)$ in 'Honeycrisp' at harvest. Similarly, there was a positive association between SSC and blush ( $r=0.32$ ) (table III). These results indicate that, as the fruit increased in size, there were also related increases in SSC and the amount of red blush. In addition, there was a positive correlation between the starch index and blush $(r=0.22)$. Changes in starch indices over time vary greatly among growing regions, as does the time required for adequate red coloration in 'Honeycrisp' [1]. The results of this study suggest that these changes are related.

Soluble solids concentration was positively correlated with TA $(r=0.25)$ during 


\begin{tabular}{|c|c|c|c|}
\hline Peel greasiness vs. IEC & $r=0.49$ & Soft scald vs. SSC & $r=0.30$ \\
\hline Direct effect & 0.18 & Direct effect & 0.09 \\
\hline Indirect effect via firmness & -0.01 & Indirect effect via IEC & 0.34 \\
\hline Indirect effect via SSC & 0.18 & Indirect effect via firmness & 0 \\
\hline Indirect effect via TA & 0.14 & Indirect effect via TA & -0.13 \\
\hline Peel greasiness vs. Firmness & $r=-0.28$ & Soggy breakdown vs. Firmness & $r=-0.71$ \\
\hline Direct effect & -0.11 & Direct effect & -0.74 \\
\hline Indirect effect via IEC & 0.01 & Indirect effect via IEC & 0.01 \\
\hline Indirect effect via SSC & 0 & Indirect effect via SSC & 0 \\
\hline Indirect effect via TA & -0.18 & Indirect effect via TA & 0.02 \\
\hline Peel greasiness vs. SSC & $r=-0.50$ & Soggy breakdown vs. SSC & $r=-0.32$ \\
\hline Direct effect & -0.36 & Direct effect & -0.26 \\
\hline Indirect effect via IEC & -0.09 & Indirect effect via IEC & -0.07 \\
\hline Indirect effect via firmness & 0 & Indirect effect via firmness & 0 \\
\hline Indirect effect via TA & -0.05 & Indirect effect via TA & 0.01 \\
\hline Peel greasiness vs. TA & $r=-0.50$ & Soggy breakdown vs. TA & $r=-0.59$ \\
\hline Direct effect & -0.26 & Direct effect & 0.03 \\
\hline Indirect effect via IEC & -0.10 & Indirect effect via IEC & -0.07 \\
\hline Indirect effect via firmness & -0.08 & Indirect effect via firmness & -0.50 \\
\hline Indirect effect via SSC & -0.07 & Indirect effect via SSC & -0.05 \\
\hline Soft scald IEC & \multicolumn{2}{|c|}{$r=-0.35$} & \\
\hline Direct effect & \multicolumn{2}{|c|}{-0.69} & \\
\hline Indirect effect via firmness & \multicolumn{2}{|c|}{0.03} & \\
\hline Indirect effect via SSC & \multicolumn{2}{|c|}{-0.05} & \\
\hline Indirect effect via TA & \multicolumn{2}{|c|}{0.35} & \\
\hline
\end{tabular}

the harvest period (table III), but there was no relationship between the two attributes after storage (table IV). The lack of marked changes in SSC and TA in previous studies suggested that these indices were not useful as maturity indicators for 'Honeycrisp' $[1,10]$.

'Honeycrisp' is known for developing greasiness, especially with extended periods of delayed cooling at warm temperatures [13]. Peel greasiness is related to changes in the wax and oil fractions in the epidermis [22]. It develops in apples of advanced maturity and within long storage periods [23]. In this study, internal ethylene concentration was correlated positively with peel greasiness $(r=0.49)$ in 'Honeycrisp' (table IV). There were also negative relationships between greasiness and firmness $(r=-0.28)$, SSC $(r=-0.50)$ and TA $(r=$ $-0.50)$ (table IV). These results indicate that as 'Honeycrisp' fruit matured they developed more greasiness. Previous studies also showed positive relationships between IEC and peel greasiness in 'Ambrosia' $(r=0.62)$ 
and 'Empire' ( $r=0.64)$ apples, as well as a negative relationship between greasiness and firmness in 'Empire' $(r=-0.71)$ [14].

After storage, soft scald was correlated negatively with IEC $(r=-0.35)$ and positively with SSC $(r=0.30)$, whereas soggy breakdown was correlated negatively with firmness $(r=-0.71)$, SCC $(r=-0.32)$ and TA $(r=-0.59)$ (table IV). The strong negative relationship between soggy breakdown and fruit firmness was likely due to the internal breakdown of the flesh tissue that is associated with the disorder. Previous studies revealed negative correlations between internal browning and firmness $(r=-0.51)$ and SSC $(r=-50)$ in 'Empire' apples, as well as between internal browning and TA in 'Ambrosia' ( $r=-0.53)$ [1].

A positive correlation was found in this study between peel greasiness and soggy breakdown ( $r=0.33$ ), as well as a negative correlation between greasiness and soft scald $(r=-0.66)$ (table IV). These results suggest that peel greasiness was more related to soggy breakdown than soft scald. There was also a negative correlation between soft scald and soggy breakdown $(r=-0.20)$. This is in agreement with the varying prominence of either disorder in a given year or among different growing regions [2, 24]. Correlation analyses also revealed strong positive relationships between epidermal greasiness and the incidence of internal browning and core browning in 'Ambrosia' and 'Empire' apples [14].

The path-coefficient analysis technique is a complementary method for correlation analysis, which provides a method of separating direct and indirect effects of the potential causal factors involved in correlations [16]. To discover the details of the relationship between the ripening attributes (independent variables) and peel greasiness, soft scald and soggy breakdown (dependent variables), path-coefficient analyses were carried out (table V).

Greasiness was correlated directly to IEC $(p=0.18)$, firmness $(p=-0.11)$, SSC $(p=$ -0.36 ), and TA $(p=-0.26$ ) (table $V)$. Internal ethylene concentration also had major indirect effects via SSC $(p=0.18)$ and TA $(p=0.14)$ on greasiness (table $V)$. A possible

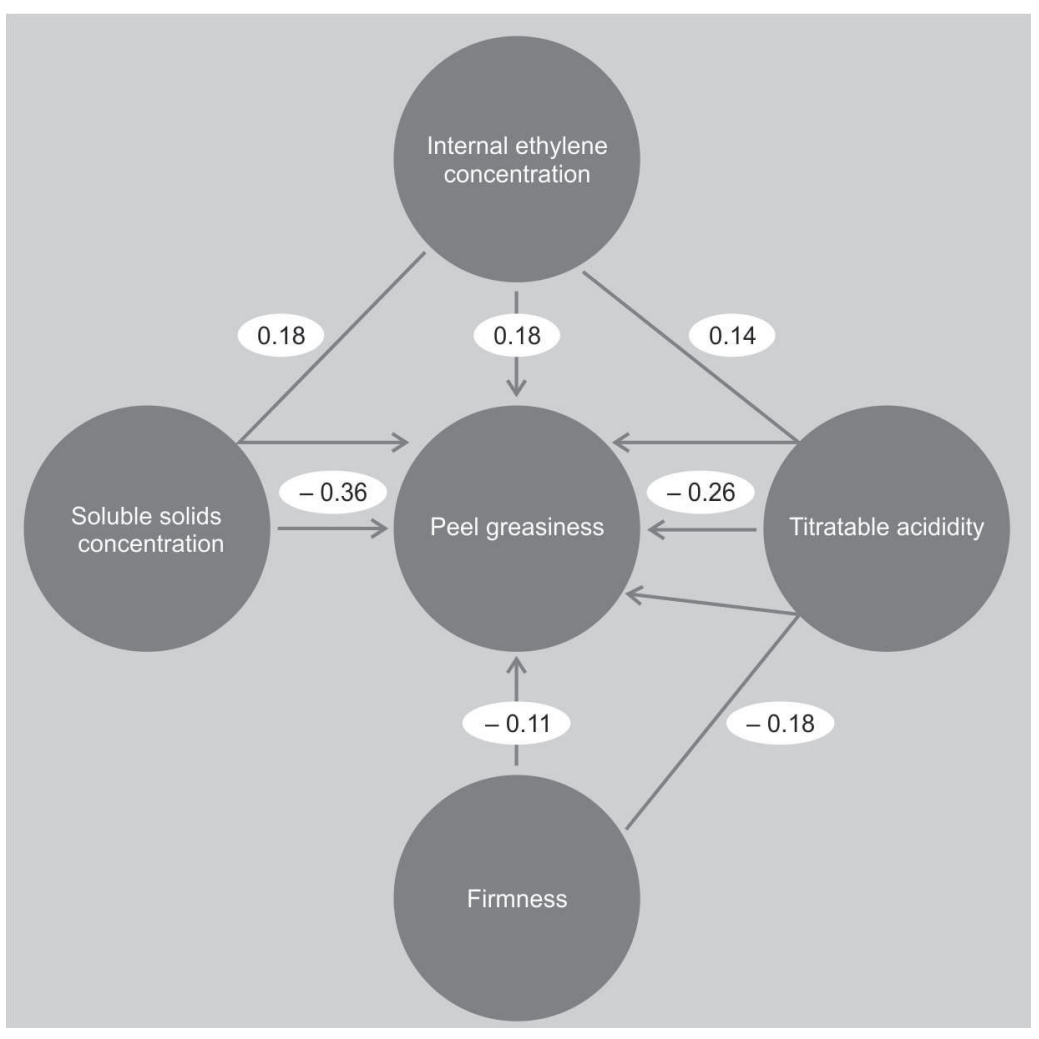

model for the interrelationships among independent ripening variables and peel greasiness as the dependent variable was drawn (figure 1). Each circle represents a variable and an arrow running between two variables shows the connection needed to complete that effect. The center circle contains the dependent variable (peel greasiness), which is endogenous in the model; its variance is considered to be explained in part by the other variables. According to this model, variance in epidermal greasiness is considered to be caused by IEC, TA, SSC and firmness, as well as extraneous sources (not in the model). Variance in TA is considered to be caused by variances in IEC and firmness, as well as extraneous sources. The $p$ value beside an arrow shows the path coefficient and it may be positive or negative.

Internal ethylene concentration was inversely associated with soft scald in 'Honeycrisp', with a relatively low value of correlation. However, the direct effect of IEC on the incidence of soft scald was very high
Figure 1.

Path diagram showing one possible model for significant correlations among independent ripening variables and epidermal greasiness as the dependent variable in 'Honeycrisp' apples. Values represent path coefficients $(p)$. 


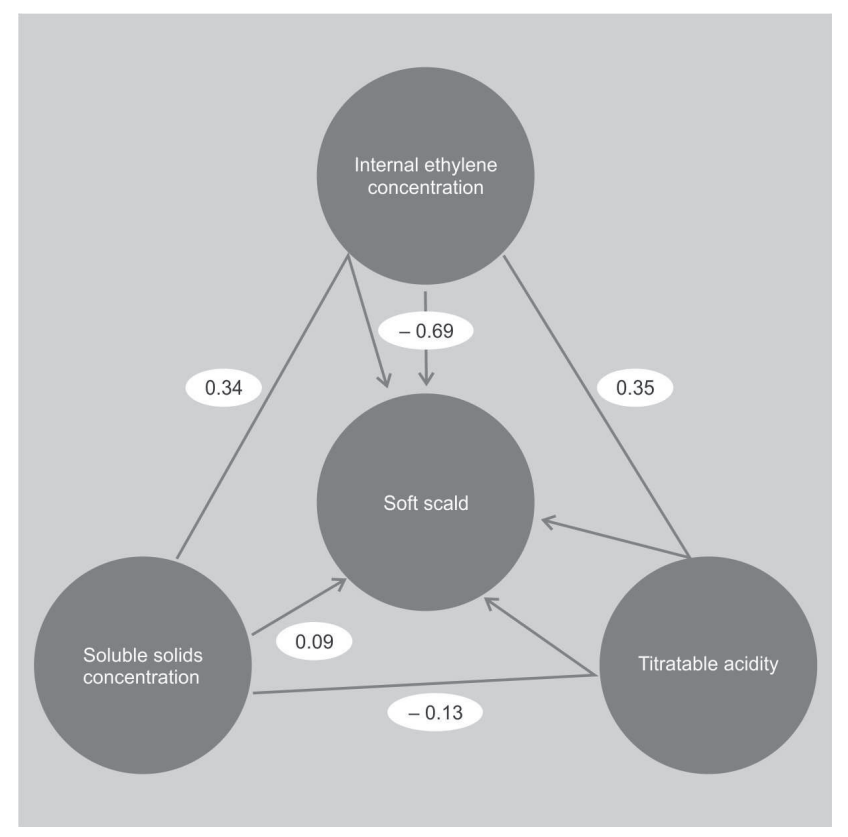

Figure 2.

Path diagram showing one possible model for significant correlations among independent ripening variables and the incidence of soft scald disorder as the dependent variable in 'Honeycrisp' apples. Values represent path coefficients $(p)$.

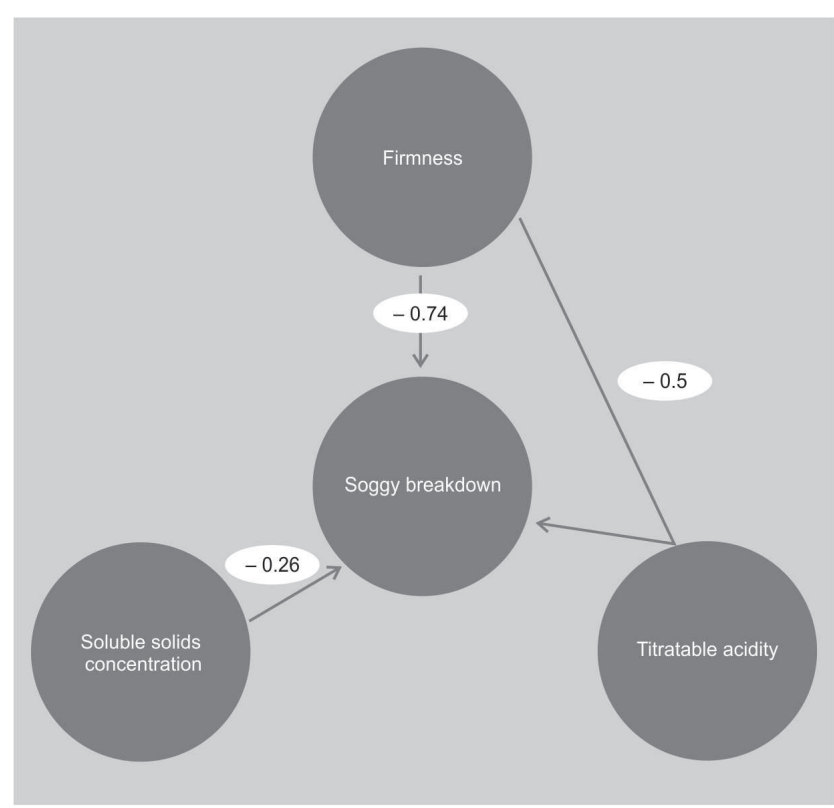

\section{Figure 3.}

Path diagram showing one possible model for significant correlations among independent ripening variables and the incidence of soggy breakdown disorder as the dependent variable in 'Honeycrisp' apples. Values represent path coefficients $(p)$.
( $p=-0.69)$, which was reduced mostly by its indirect effect on TA $(p=0.35)$. The indirect contribution of IEC to the incidence of soft scald via SSC ( $p=0.34)$ was also notable (table $V)$. Firmness was inversely associated with soggy breakdown (the higher the firmness, the less incidence of soggy breakdown), with a very high direct effect $(p=-0.74)$. The correlation between TA and the incidence of soggy breakdown was significant $(r=-0.59)$, but mostly because of the indirect effect of firmness $(p=-0.50)$ and not TA itself (table $V$ ). Unlike in greasiness and soft scald, the direct or indirect effects of IEC on the incidence of soggy breakdown were invisible, which were unpredictable. Possible models for the interrelationships among independent ripening variables and the incidence of soft scald or soggy breakdown as the dependent variable were drawn (figures 2, 3, respectively).

\section{Conclusion}

Pearson correlation analysis revealed consistent relationships, but with different intensities, between IEC and SSC or TA and between firmness and TA for 'Honeycrisp' during the harvest period and after storage. In general, these correlations can be interpreted as the higher the IEC, the lower the sugars and acidity of the fruit. Correlation analyses also revealed significant connections among peel greasiness and incidence of soft scald and soggy breakdown with some ripening indices in 'Honeycrisp'. The results of the path-coefficient analyses suggest that associations among ripening indices and with individual disorders vary in 'Honeycrisp' apple.

\section{Acknowledgements}

The authors wish to thank the Ontario Apple Growers, Norfolk Fruit Growers' Association, and the Agricultural Adaptation Council for their support. 


\section{References}

[1] Watkins C.B., Erkan M., Nock J.F., lungerman K.A., Beaudry R.M., Moran R.E., Harvest date effects on maturity, quality, and storage disorders of 'Honeycrisp' apples, HortSci. 40 (2005) 164-169.

[2] Watkins C.B., Nock J.F., Weis S.A., Jayanty S., Beaudry R.M., Storage temperature, diphenylamine, and pre-storage delay effects on soft scald, soggy breakdown and bitter pit of 'Honeycrisp' apples, Postharvest Biol. Technol. 32 (2004) 213-221.

[3] Meheriuk M., Prange R.K., Lidster P.D., Porritt S.W., Postharvest disorders of apples and pears, Agric. Can. Publ. 1737/E (1994).

[4] DeEll J.R., Ehsani-Moghaddam B., Preharvest 1-methylcyclopropene treatment reduces soft scald in 'Honeycrisp' apples during storage, HortSci. 45 (2010) 414-417.

[5] DeEll J.R., Ayres J.T., Murr D.P., 1-Methylcyclopropene concentration and timing of postharvest application alters the ripening of 'McIntosh' apples during storage, HortTechnol. 18 (2008) 624-630.

[6] Fan X.T., Mattheis J.P., Blankenship S.M., Development of apple superficial scald, soft scald, core flush, and greasiness is reduced by MCP, J. Agric. Food Chem. 47 (1999) 3063-3068.

[7] Watkins C.B., Nock J.F., Effects of delays between harvest and 1-methylcyclopropene treatment, and temperature during treatment, on ripening of air-stored and controlled-atmosphere-stored apples, HortSci. 40 (2005) 2096-2101.

[8] Jung S., Watkins C.B., Involvement of ethylene in browning development of controlled atmosphere-stored 'Empire' apple fruit, Postharvest Biol. Technol. 59 (2011) 219-226.

[9] Tong C., Krueger D., Vickers Z., Bedford D., Luby J., El-Shiekh A., Shackel K., Ahmadi H., Comparison of softening-related changes during storage of 'Honeycrisp' apple, its parents, and 'Delicious', J. Am. Soc. Hortic. Sci. 124 (1999) 407-415.

[10] Wargo J.M., Watkins C.B., Maturity and storage quality of 'Honeycrisp' apples, HortTechnol. 14 (2004) 496-499.

[11] DeEll J., SmartFresh and storage of 'Honeycrisp' apples', Compact Fruit Tree 43 (2010) 20-23.

[12] Baldwin B.J., Goodner K.L., Mattheis J.P., Brecht J.K., Response of four apple cultivars to 1-methylcyclopropene treatment and controlled atmosphere storage, HortSci. 40 (2005) 1534-1538.

[13] DeLong J.M., Prange R. K., Schotmans W.C., Nichols D.S., Harrison P.A., Determination of the optimal pre-storage delayed cooling regime to control disorders and maintain quality in 'Honeycrisp' apples, J. Hortic. Sci. Biotechnol. 84 (2009) 410-414.

[14] Ehsani-Moghaddam B., DeEll J.R., Correlation and path-coefficient analyses of ripening attributes and storage disorders in 'Ambrosia' and 'Empire' apples, Postharvest Biol. Technol. 51 (2009) 168-173.

[15] Blanpied G.D., Silsby K.J., Predicting harvest date windows for apples, Cornell Coop. Ext. Publ., Inf. Bull. \#221 (1992).

[16] Wright S., The method of path coefficients, Ann. Math. Stat. 5 (1934) 161-215.

[17] Blankenship S.M., Unrath C.R., Use of ethylene production for harvest-date prediction of apples for immediate fresh market, HortSci. 22 (1987) 1298-1300.

[18] Blanpied G.D., Bramlage W.J., Dewey D.H., Labelle R.L., Massey J.L.M., Mattus G.E., Stiles W.C., Watalla A.E., A standardized method for collecting apple pressure data, Cornell Coop. Ext Publ., Inf. Bull. \#74 (1978).

[19] DeEll J.R., Khanizadeh S., Saad F., Feree D.C., Factors affecting apple fruit firmness a review, J. Am. Pomol. Soc. 55 (2001) 8-27.

[20] Johnson D.S., The effect of flower and fruit thinning on the firmness of 'Cox's Orange Pippin' apples at harvest and after storage, J. Hortic. Sci. 67 (1992) 95-101.

[21] Saei A., Tustin D.S., Zamani Z., Talaie A., Hall A.J., Cropping effects on the loss of apple fruit firmness during storage: The relationship between texture retention and fruit dry matter concentration, Sci. Hortic. 130 (2011) 256-265.

[22] Morice I.M., Shorland F.B., Composition of surface waxes of apple fruits and changes during storage, J. Sci. Food Agric. 24 (1973) 1331-1339.

[23] Leake A.L., Hoggett S.M., Watkins C.B., Solving the greasiness problem in Granny Smith apple fruit, N.Z. Orchard. 62 (1989) 24-26.

[24] Moran R.E., DeEll J.R., Murr D.P., Effects of preconditioning on the occurrence of postharvest storage disorders in 'Honeycrisp' apples, HortSci. 45 (2010) 1719-1722. 


\section{Relaciones entre las características de maduración tras la cosecha y las anomalías de conservación en la manzana 'Honeycrisp'.}

Resumen - Introducción. El objetivo de nuestro estudio fue estudiar las relaciones entre determinadas características de la maduración de las manzanas 'Honeycrisp' en el momento de la cosecha y tras su almacenamiento y las consecuencias directas e indirectas de dichas características en el aspecto grasiento de la piel, el escaldado blando y la vitrescencia de las frutas durante su conservación; se utilizaron análisis de correlación y de coeficiente de caminos. Material y métodos. Las frutas se recogieron en un cultivo comercial al menos cinco veces durante el periodo de cosecha comercial desde 2008 hasta 2011. Durante dos años de dicho periodo, las frutas se almacenaron al aire durante tres meses a $3{ }^{\circ} \mathrm{C} y / \mathrm{o}$ en una atmósfera controlada (1-2 $\mathrm{kPa} \mathrm{O}_{2}+1-2 \mathrm{kPa} \mathrm{CO}$ ) durante 6 meses a $3{ }^{\circ} \mathrm{C}$. Las frutas se analizaron en el momento de la recogida y tras su almacenamiento. Resultados y discusión. Se detectaron correlaciones negativas entre la concentración interna de etileno (CIE) y la concentración de sólidos solubles (CSS) o la acidez valorable (AV) (cuanto mayor es la CIE, menores son la CSS y la AV), y se registraron correlaciones positivas entre la firmeza y la AV (cuanto mayor es la firmeza, mayor es la AV). Durante el almacenamiento de las manzanas, la mayor grasa en la piel y la mayor vitrescencia se asociaron a una menor firmeza, y a valores reducidos de CSS y de AV. Del mismo modo, se detectaron correlaciones negativas entre la incidencia de escaldado blando y la CIE o la piel grasa. Los resultados de los análisis de coeficiente de caminos sugieren que, en el caso de la manzana 'Honeycrisp', las interrelaciones entre las características de maduración tras la cosecha y cada una de las anomalías de almacenamiento consideradas de forma individual son diferentes. Se presentaron tres modelos de caminos posibles que mostraban la interrelación entre las características de maduración (variables independientes), y el aspecto grasiento de la piel, el escaldado blando y la vitrescencia (variables dependientes).

Canadá / Malus / manzana / maduración en postcosecha / enfermedades postcosecha / calidad 